\title{
Due Process and Budget Implementation: An Evaluation of Nigerian Public Sector Auditing
}

\author{
Olurankinse, Felix \\ Department of Accounting \\ Adekunle Ajasin University \\ Akungba-Akoko, Ondo State, Nigeria
}

Received: April 22, 2012

Accepted: July 19, 2012 Published: December 1, 2012

doi:10.5296/ajfa.v4i2.1689

URL: http://dx.doi.org/10.5296/ajfa.v4i2.1689

\begin{abstract}
As the state is experiencing growth in her population, so is the increase in the demand of the people in terms of provisions of social and infrastructural facilities. As economist will say 'Human wants are unlimited but the means to satisfy them are limited. There is therefore the need to utilize these scarce resources to the full benefit of the citizenries. To do this, we need an appropriate tool of accounting called budget that will serve as a composite framework of implementing government policies. Budget in the public sector of Nigeria has almost become a ritual or a yearly affairs which though good in content but without appreciable results. The issue of budget implementation has long been a source of concern to the public. As good as our budget is mostly in terms of preparation and contents; it is kept in shelves after approval as a historical book and never consulted. There are wide range of disparity between budget and accomplishments. It is against this background that government and auditors introduce new measures and strategies aimed at checking wasteful expenditures and keeping budget in line with global practice. The objective of the paper therefore is to examine few of these measures and to determine their implications on budget implementation. The paper concluded that all the new audit trends are indispensable for the efficiency and effectiveness of budget performance. However, the paper recommended the need to enact enabling laws that will ensure the workability of these new audit concepts.
\end{abstract}

Keywords: Due process, Cost audit, value for money, Efficiency, Effectiveness, Economy. 


\section{Introduction}

The term Public sector simply refers to the part of the economy that is controlled by the government for the purpose of providing basic government services. These basic services that the government need to provide are so enormous due to increase number of people they service. As economist would put it "human wants are unlimited, but the means to satisfy them are limited", this therefore call for the use of an efficient management tools that will harness the limited resources for optimal use. One of the machineries of government that can be used for this purpose is budget. Budget making and budget implementation involve the process of identification of public needs and the determination of the quality of goods and services to satisfy these needs through the political process, by economic analysis with the overall development plan objectives. Government prepares budget inform of public policy to serve as a driver through which her mission could be achieved. As good as our budget is, the performance of which can be measured in terms of accomplishment is nothing to write home about. Budget accomplishment is far from reality and the disparity between budget and accomplishment are so wide and kept on abating as years pass by. The question that could readily come to mind is why is re occurrence of budget failure? Could it be that it is ill conceived or ill planned? Could it be ascribe to poor monitoring and implementation?. The need to provide answers to these questions gave impetus for this study. Due process

\section{Literature Review and Theoretical Framework}

The practice of budgeting, as it is now understood, originated in the central government of Great Britain. It later developed gradually, as a result of parliament's struggle to obtain control over the finance of the crown. In 1217, it was declared in Magna Charta that "No cottage or aid shall be imposed in the kingdom unless by the common council of realm. After the revolution of 1688, parliament now approved the right to authorized expenditure by the crown as well as taxation apart from items in the sovereign's civil list, which was gradually reduced until it covered only the personal expenses of royal family". (Bendlebury, 2005). Parliament now began to fix government total expenditure and to prescribe or appropriate the amount to be spent for parliamentary purposes (California Department of Finance, 1998). A budget is a framework for revenue and expenditure outlays over a specified period usually one year. It is an instrument stipulating policies and programmes aimed at realizing the development objectives of a government. Budgeting and its process in Nigeria remain problematic both in the areas of preparation and implementation, hence, the need for adequate control aimed at improving effective resources utilization at the budget implementation stage. To achieve these objectives, there is need for the introduction of new audit waves such as the value for money audit, Due process, cost audit and so on. Omolehinwa (2003) viewed Budget as the plan of dominant individuals in an organization expressed in monetary terms and subject to the constraints imposed by other participants and the environment indicating how the available resources may be utilized to achieve whatever the dominant individual agreed to be the organization's proprieties". Meigs and Meigs, (2004) defined budgets as a comprehensive financial plan, setting forth the expected route for achieving the financial and operational goals of an organization". Budgeting in the early stage of its evolution was primarily concerned with serving the purpose of legislative 
accountability (Johnson, 1992), Jones and Bendlebury (2005) argued that the origin of a budget could be traced back to Britain when the parliament attempted to exercise control over the activities of central government.

According to Nigeria's Finaical Regulations (2000), before ministries and spending agencies can incur an obligation to make expenditures, they must secure spending authorization from the Ministry of Finance through the use of warrants. This warrant will authorize officers controlling votes to incure expenditure in accordance with the approved estimates subject to any reserved items. If the Appropriation Act has not come into operation at the beginning of the year, a provisional General Warrant may be issued to ensure continuity of the services of government at a level not exceeding those of the previous year. The length of period of spending authorization is determined in functional cash flow forecast for the period when payments are anticipated. During the phase of budget implantation, there are many possibilities for interventions and manipulations in view of the fact that officials have a great amount of discretionary power to decide which spending ministry or agency will be granted spending authorization (Federal Republic of Nigeria, 2000). In spite of the specific nature of appropriation laws, the commitment phase of the expenditure process is a fertile ground for corrupt activities. The most frequent is the partial or total disregard of procurement regulations and procedures, where they exist.Procurement procedure and regulations specify the price and quality of goods and services that are authorized in the budget. They also specify the delivery schedule, terms of delivery and payment as well as contingent supplementary services such as maintenance and warranties. In addition, they specify the procedure, which will have to be followed by competing bidders' prescription for price quality and quantity as well as terms of delivery. These are often disregarded in favour of one supplier who is ready to offer a bribe to corrupt officials. Another possible case of corruption is the ordering of goods and services, which are not authorized in the budget. In this case, corrupt officials will simply disregard the budget as approved by the legislature and will purchase, for instance, luxury cars instead of trucks or other needed equipment.

\section{System of Budgeting and Implementation: An Overview}

Budgeting in the public sector is a document or a collection of documents that refers to the financial condition of the government (Turns, 2006). A budget is prospective in the sense that it refers to expected future revenue and expenditure, in the Federal Government circle the budget is greatly limited in legal status. It is the official recommendation of the president to the congress. In other to provide for a responsible government, budgeting is generated to a cycle. The cycle allows for the system to absorb and respond to new information and in doing so the government is held accountable for its action though it should be recognized that many factors curtail the extent to which the president can make major changes in the budget. In some states, preparation and authority is not always given to governors while some have responsibility for preparation and submission, some share budget making authority with other elected administrative officer, civil servant, political appointees, legislative leader, or some combination of these officers. In the federal government level, preparations start from, large agencies. The agencies begin by assessing their programmes and considering which programmes required revision and whether new programmes should be recommended. At 
same time, estimates are made by the president's staff regarding anticipated economic trends in order to determine available revenue under existing tax legislation. The budget approval in the public sector (Government) occurs at three stages namely ministerial approval, executive approval and legislative approval. The preparation of budget phase commences five months before the beginning of the fiscal year. Guidelines are issued from the ministry of budget and planning in a form of circular. When the circular demanding the budget estimates to prepare is received by each ministries and department, a departmental committee of budget estimate is set up by each ministry and extra ministerial department. The committee is headed by the ministerial head of budget and personnel. It has its function as consideration and reconciliation of the budget proposals submitted by various departmental branches, division and units of the ministry.

\section{Ministerial Approval Phase}

Each ministry submits their estimates to the Ministry of Budget and Planning for further consideration and approval. The Ministry of Budget and Planning in turn set up a committee called "Draft Committee" for the review of draft estimates submitted by the ministries. These committee asked each ministry or department to come and defend its proposals; having concord on the proposal, the budget department aggregate the budget in the form of a consolidated estimates of revenue and expenditure. This is sent to the presidents for its approval.

\section{ii. Executive Council Approval Phase}

The president on receipt of the advanced proposal as approved by the budget and planning present the draft estimate before his cabinets members known as the council of ministers for further consideration and approval. This council discusses and agrees the estimates with the president's political priorities of government and therefore the president gives his executives approval of the draft estimates before sending it to house of legislature inform of appropriation bills.

\section{iii. Legislative Approval Stage}

The National Assembly comprises the house of representative and the house of senate. The president presents his budget package to the National assembly at a joint meeting of the two houses of assembly. This meeting is known as BUDGET SESSION. It is up to the national assembly to approve, modify or rejects the Bills. In each house there are standing committees, which relates to the ministries and departments. At such committees, each ministries and departments are invited to defend the increasing budgeting allocation, in justification of their Programmes. The house debates the bill and makes modifications where necessary. After the house must have considered and reconciled the budgets estimates in the light of national economic and priorities then the appropriation committee is brought for appropriation purposes. If the house are convinced and satisfied with the proposals, each of them will approve the budget. Where there are discrepancies in opinion on some particular items, the two houses appoint finance committee that would resolve such differences. The resolution of the finance committee is final on the difference. Afterward they both sit to approve the 
budget. On approval of the national assembly the budget is sent back to the president for his assents and signature. And consequently it becomes the appropriation act. These will now be printed and distribute to the ministries and department inform of approved estimates.

\section{New Trends in Cost Monitoring and Auditing}

Value for Money Audit

The scope of government auditing has been widened over the years by the demand for independent verification of information to the extent that it can no longer be limited to the audit of financial operations. Government auditing now extends to financial audit, regulatory audit, economy, efficiency, and effectiveness audit. The audit objectives has been viewed traditionally as an independent examination of the financial statements of an entity followed by the expression of independent opinion as to the truthfulness and fairness of the financial statement against the criteria of generally accepted accounting principles and standards However, in the case of government accounting, the general absence of the profit motive and the presence of the provision of social and economic services have combined to extend the audit objective to include an ascertainment of whether the establishment being audited is achieving the purposes for which its programmes are authorized and whether it is doing so economically, efficiently and effectively. Value for money is the concept that seeks the maximization of the use of scarce resources for the welfare of the public by ensuring that activities and programmes are carried out at low cost and to high standard. In order to achieve this phenomenon, three elements are usually covered and these are: Economy, Efficiency and Effectiveness. According to Afemishe (2003), these three elements of value for money can be described as follows:

a. Economy is the practice by management of the virtues of thrift and good housekeeping. An economical operation acquires resources in appropriate quality and quantity at the lowest cost.

b. Efficiency is making sure that the maximum useful output is gained from the resources devoted to each activity, or alternatively, that only the minimum level of resources are devoted to achieving a given level of output. The efficiency of an operation could be said to have increased if either lower cost were used to produce a given amount of output, or a given level of cost has resulted in increased output.

c. Effectiveness is ensuring that the output from any given activity is achieving the desired results. There is, therefore, the need to establish that the desired goals are being achieved in order to evaluate effectiveness.

The type of interrelationship among these three elements is that all of them must be in place before the assessment of value for money can be said to complete. Right things must be done, using the right method and at minimum cost. For instance, as much as effectiveness is linked with the achievement of set objectives, it is also important to expect that the objectives are achieved by the application of the right methods that is, efficiency. The use of a sledge 
hammer to kill a housefly, though effective is not efficient. The application of value for money concept to auditing leads to the concept of Value for Money (VFM) audit. It is applicable to both the private and public sector, but more emphasis has been placed on its application to the public sector. It is related to the extent to which funds are spent economically, efficiently and effectively. It is also referred to as Comprehensive Audit or Efficiency Audit.

Due Process

On a continuous basis and in both the private and public sectors, efforts are usually made, to seek how to improve on the ways activities are carried out, if there is to be progress in the results being sought to be achieved. More importantly, in the public sector, those at the helm of affairs must make deliberate effort to improve on the system already put in place in all the three tiers of government if they must remain relevant in the global village which the world is turning into. The concept of control as applicable to the public sector has been undergoing various changes from one country to the other in the recent past. Each nation has been formulating policies aimed at improving resources utilization at the budget implementation stage. Considerable efforts have been made to find new techniques of control and to introduce institutional changes and improvements to the types of controls applied. In an effort to exercise control on the expenditure of government, it is not sufficient to rely on the fact that expenditure items have been provided for in the approved budget (via the Appropriate Act). At the implementation stage, approval for releasing the money must be tied to availability of funds to the extent to which the revenue budgeted for has been earned. Therefore the process of controls involved under the overall expenditure control structure should cover monitoring of the activities, for example, contract approval for payment and release of funds. There must be commitment by top management staff at the relevant tier of government to the new ways of doing things (Corporate governance).

In Nigeria, the relatively long period of military rule had almost eroded the basic economic structures that had been developed since independence. Consequently, the Obasanjo administration was faced with the task of seeking ways of reversing the trend of decadence in the nation.At the inception of his government in 1999, the president emphasized that his administration had adopted transparency, equity, justice and accountability as its guiding principles and policy imperatives. These principles are to ensure commitment to public policies and good governance (Nwankwo, 2004).

Budget Monitoring and Price Intelligence Unit (BMPIU)

It has always been a recurrent observation of those reviewing the budgetary performance of governments in Nigeria that implementation is our problem. The problems experienced during implementation may as well have originated in formulation. Therefore the axiom "Prevention is better that cure" could be appropriate here. It is on the basis of this view that evaluation of completed programmes and projects were initiated as an ex-post control but with an impact that goes beyond the budget implementation phase. The evaluation consists of an assessment of progress and its impact, so that areas of success and failure in implementation can be identified. Evaluation in the context of the above explanation serves 
mainly to link formulation and implementation of budgets and is used by the executive. It is also possible to view evaluation as a tool for ensuring both transparency and accountability. Due process involves ensuring strict compliance with laid-down rules and procedures, guiding the process of contract invitation, contract award and contract implementation. This is with a view to ensuring that government's resources are managed in such a way that they are not wasted.

The BMPIU has become synonymous with Due Process. In fact, it has become to be known as the Due Process Unit because of the emphasis on the need to follow due process in all the different tiers of government and parastatals. It is noteworthy that the term "Due Process" simply means the appropriate way or proper method or expected approach or normal way of doing something. It is, therefore, merely an awakening or revival of the application of the procedures already put in place earlier but for some time abandoned due to corruption and moral decadence.

\section{Cost Audit}

Cost audit is the detailed checking of costing system, techniques and accounts to verify their correctness and to ensure their adherence to the objectives of cost accounting. Chukwu (2005) opines that cost audit is a systematic and accurate recording of detailed transactions and operations of manufacturing, contracting, extracting, transporting, supplying, servicing etc. so as to show the actual cost of each individual piece of work, service or separations of the business. Cost audit is, therefore the verification of the correctness of cost accounts and adherence to the cost accounting plans. One of the basic principles of auditing is that the auditor should not only be seen as independent but must be truly independent. In order to ensure the total independent of the auditors in the public sector, the auditing system must be overhauled with particular reference to the appointment and removal of auditor especially at the higher level. Furthermore, the staff of the office of the Auditor-General of the Federation must be properly trained to focus on relevant value-for-money audits in support of government budget implementation objectives.

\section{Method and Discussion of findings.}

The study covered a period of ten years between 2001 and 2011. This period is believe to be good enough to make a position in respect of budget implementation and Due process as it falls within the period of democratic dispensation in Ondo state. The design used for this study is survey design. The paper makes use of structured questionnaires as a source of data collection. A sample size of five hundred (500) respondents was chosen through purposive sampling .Data collected were analyzed with the use of descriptive analysis. Five hundred questionnaires were distributed and administered to the budget officers and accounting officers of the various units of government in the following order: 


\section{Macrothink Institute ${ }^{\mathrm{TM}}$}

Units of government

Ministries

Agencies

Corporations

Institutions

Local Government
Asian Journal of Finance \& Accounting

ISSN 1946-052X 2012, Vol. 4, No. 2

Number of questionnaires distributed

100

100

100

100

100

$\underline{500}$

The questionnaires were structurally designed and contain questions that can illicit answers on the five (5) key areas that bothered on Due process and budget implementation. These key areas are:

i Awareness of budget formulation

ii Adequacy of budget formulation

iii Adherence to budgetary provisions

iv Due process compliance

V Effectiveness of monitoring and implementation.

\section{Discussion of findings}

Four questions each were set on each of the 5 key areas of budgeting that were looked into. Each questionnaire contain 20 questions and this sum up to a total of 10,000(20x500) in all that were administered. Out of the 500 questionnaires that were administered, only 420 were returned. The break down of the returned questionnaires is as follows:

Ministries

90

Agencies

80

Corporations

Institutions 
Result of Responses of Questionnaires Administered

QUESTIONS TYPE

Q1. Whether there Is awareness Yes $\quad \%$

$700 \quad 35$

1180

59

$\%$

Total

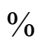

Of budget formulation

Q2. Whether there is inadequacy

Of budget formulation

Q3. Whether budget provisions are 900

Adhere to

Q4. Whether there is compliance

62.5

10,000

100

With due process

Q5. Whether budgets are effectively

650

32.5

1350

67.5

10,000

100

Monitored \& implemented

\section{Source: Questionnaires Administered 2012}

The responses from the questionnaires administered as can be seen from the result indicate a higher percentage of 'No' response in comparison with the 'Yes' response for virtually all the questions in the questionnaires that were administered. What the result suggests is that the people that are concern with budget formulation are not fully carried along and this accounted for the inadequacy of budget formulation. Besides, there is lack and disrespect for Due process because of low level of compliance with budgetary provisions. In terms of monitoring and implementation, $67.5 \%$ of the responses show that budget are not well monitored and not fully implemented and this is evidence by so many uncompleted and abandoned projects littered around.

\section{Conclusion}

The essence of this paper is to provide a way of getting out of the jinx of continual and repited adverse budgetary performance. The paper reveals the need for Due process in budget implementation in order to secure best value in terms of allocation and utilization of scarce resources that are available to the society.

The paper identified the overall characteristics of a good public procurement system to include a strong legal, organizational and professional framework to make the system robust and effective. Furthermore, the paper highlighted the need for a budget implementation process to be carried out under the constraint of value-for-money, accountability and transparency. It highlighted and discussed, in same details, the elements of value-for money; economy, efficiency and effectiveness. A good public procurement system delivers value-for-money in procurement activities. Finally, the due process mechanism has been discovered to have "struck the right chord" confirming that system control is the correct way 
to go where moral suasion, threats, probes and emphasis on reparation have proved unsuccessful in guarding resources. Therefore, the study has shown that due process, value for-money audit and cost audit are necessary and imperative in budget implementation. Due Process" mechanism is a model which has proved its effectiveness.

\section{Recommendation and Policy Implementation}

There is the need to encourage professionalism in post project review technique of value for money concept, performance measurement and benchmarking so that the continuous process and improvement suggested here can be imbibed as a national corporate culture. It is recommended that due processes and value-for-money audits should remain in our policy for economy, efficiency and effectiveness in the use of resources. It is important to underpin the due process mechanism with structures, systems, and skills in order to ensure that it endures. Due process is too centralized and must be decentralized in order to move procurements by the spending units from the threshold of the resident due process team.

\section{References}

Ademikhe, S.T. (2005). Pedagogy of the Probe Panel and Auditing. The Nigeria Accountant, 3(4), 33-46.

Afemikhe, S.O. (2003). The Pursuit of Value for Money. Ibadan, Nigeria Spectrum Books Limited, 75- 162.

Bendlebury, A. (2005). Controlling Government Spending: the Ethos, Ethnics and Economics of Expenditure Management. New York, Oxford University Press, 85-102

Chekwu, I. K. (2205). Management Resources. Full implementation Resources and Budgeting. Retrieved from www.humtreasry.gov.uk/documents/publicaspendingandservicies

California Department of Finance. (1998). Budgeting and the Issues Involved. Retrieved from http:/www.dof.cagor/fiscalhistory.htm.

Chartered Institute of Management Accountant. (1982). Journal of Management Accounting, $5(2), 37-45$

Johnson, I. E. (1992). Public Sector Accounting and Financial Control, Lagos, Nigeria, Financial Training Ltd, 132-144

Meig. W., \& Meig, F. (2004). Accounting the Basic Business Decision New York, USA, MCGraw-Hill Book Company, 51-68

Moss, D (2000). Comments on the Fatal Defect in the Federal Accounting System. Public Budgeting and Finance, winter, 20(4), 12-25

Nwankwo, S. (2004). Due Process in Public Accounting. The Nigerian Accountant 5(2), $34-42$.

Okunrounmu, T.O.(2006) Transparency, Probity and Accountability Fiscal Operation as a panacea for Economic Development. CBN Economic and Financial Review, 3(4), 91-103. 


\section{Macrothink}

Asian Journal of Finance \& Accounting ISSN 1946-052X

Olowu, J., \& Erero, H. (1995). Explanation on 1991 Budget and the National Rolling Plan (1991-1993). Nigeria Institute of Management Review, 3(2), 42-53.

Omolehinwa, E. (2003). Government Budgeting in Nigeria, Lagos, Nigeria, Pumark Nig Ltd, $1-14$.

Turn, A.J. (2006). Use of Budgetary Techniques in Service Companies. Journal of Institute of Chattered Accountant of Nigeria, 36(2), 34-42.

Uzoma, A. M. (1994) Relation of the Budget to Employee Motivation. The Role of Participation in the Budget-Construct Revisited. Nigeria Financial Review, 1(5), 40-50.

World Bank Evaluation Department. (1998). Public Sector Performance the Critical Role of Evaluation. Retrieved from http./inweb18.worldbank.org. 